九州大学学術情報リポジトリ

Kyushu University Institutional Repository

\title{
Net Fine Root Carbon Production in Pinus densiflora, Pinus koraiensis, Larix leptolepis and Quercus acutissima Stands, Gongju area, Chungnam Province, Korea
}

Park, Gwan-Soo

Division of Environmental Science and Forest Resources, College of Agriculture \& Life Sciences, Chungnam National University

Kang, Gi l-Nam

Chungnam Forest Environment Research institute

Lee, Sang-Jin

Division of Environmental Science and Forest Resources, College of Agriculture \& Life Sciences, Chungnam National University

Lee, Hang-Goo

Lee_Hang-Goo]

他

https://doi.org/10.5109/17803

出版情報：九州大学大学院農学研究院紀要. 55 (1)，pp.73-76，2010-02-26. Faculty of Agriculture， Kyushu University

バージョン :

権利関係 : 


\title{
Net Fine Root Carbon Production in Pinus densiflora, Pinus koraiensis, Larix leptolepis and Quercus acutissima Stands, Gongju area, Chungnam Province, Korea
}

\author{
Gwan-Soo PARK ${ }^{1}$, Gil-Nam KANG ${ }^{2}$, Sang-Jin LEE ${ }^{1}$, Hang-Goo LEE ${ }^{1}$, \\ Si-Young $\mathrm{LEE}^{3}$, Hee-Mun $\mathrm{CHAE}^{4}$ and Shoji OHGA* \\ Laboratory of Forest Resources Management, Division of Forest Ecosphere Management, \\ Department of Forest Products Science, Kyushu University, \\ Sasaguri, Fukuoka 811-2415, Japan \\ (Received November 17, 2009 and accepted November 19, 2009)
}

\begin{abstract}
This study was carried out to estimate annual carbon production by fine root in Pinus densiflora, Pinus koraiensis, Larix leptolepis and Quercus acutissima stands of Gongju region, Korea. Soil samples were taken at 0-30 cm, 30-60 cm, and 60-90 cm soil depths from April to November (monthly increment method) in 2007 using soil sampler. Fine root carbon biomass was higher at $0-30 \mathrm{~cm}$ soil depth than in the other soil depths. Total fine root carbon biomass at 0-90 cm soil depth was highest in Larix leptolespis stand among the four study stands. Net fine root carbon production $\left(\mathrm{kg} \mathrm{ha}^{-1} \mathrm{yr}^{-1}\right)$ in Pinus densiflora, Pinus koraiensis, Larix leptolepis and Quercus acutissima stands were $889 \mathrm{~kg}, 2,266 \mathrm{~kg}, 851 \mathrm{~kg}$, and $1,121 \mathrm{~kg}$ at 0-30 cm soil depth, respectively. Total net fine root carbon production $\left(\mathrm{kg} \mathrm{ha}^{-1} \mathrm{yr}^{-1}\right)$ was highest in Pinus koraiensis stand among the four study stands. Fine root turnover rates in the four stands were ranged from 0.59 to 2.63 at $0-30 \mathrm{~cm}, 30-60 \mathrm{~cm}$, and $60-90 \mathrm{~cm}$ soil depth.
\end{abstract}

\section{INTRODUCTION}

After the earth's average air temperature reached an all-time high recently, many scientist expressed concern about the potential for significant global warming as a result of the increased carbon dioxide $\left(\mathrm{CO}_{2}\right)$ and other greenhouse gases $\left(\mathrm{CFC}_{\mathrm{s}}, \mathrm{CH}_{4}\right.$, and $\left.\mathrm{N}_{2} \mathrm{O}\right)$ within the coming century (Schlesinger, 1991; Hansen, 1993). Even small changes in temperature can have dramatic impacts on the earth complex atmosphere, ocean, land, and life systems (Hair and Sampson, 1992). Increasing population and economic activity will increase the concentration of $\mathrm{CO}_{2}$ in the atmosphere and may accelerate changes in global climate which may have important consequences for the earth's ecology.

Forests have received considerable attention because they are a major sink for $\mathrm{C}$ cycle. The carbon sinks of plants include roots, shoots, and when plants are exposed to large seasonal climatic changes, storage reserves for maintenance during and after the period of dormancy. Not like a shoots, fine root carbon dynamics are seldom measured directly because these studies are labor intensive (Burke and Raynal, 1994) and also sampling methods are not standardized (Laurenroth et al., 1986; Nadelhoffer and Raich, 1992; Singh et al., 1984; Vogt et al., 1986). However, it is true that a large part of the carbon in

Division of Environmental Science and Forest Resources, College of Agriculture \& Life Sciences, Chungnam National University, Daejeon, Korea

${ }^{2}$ Chungnam Forest Environment Research institute, Gongju, Korea

${ }^{3}$ Division of the Professional School of Disasters Prevention Technology, Kangwon National University, Samcheok-Si, Korea

${ }^{4}$ Korea Climate Change Countermeasure Research center, Chuncheon-Si, Korea

* Corresponding author (E-mail: ohga@forest.kyushu-u.ac.jp) deciduous forests is allocated in fine root, yet this process is seldom measured (Burke and Raynal, 1994).

The objective of this study was to estimate the amount of annual C production by fine root in Pinus densiflora, Pinus koraiensis, Larix leptolepis, and Quercus acutissima stands of Gongju region, Chungnam Province, Korea.

\section{MATERIALS AND METHODS}

This study was conducted in 2007 in Pinus densiflora, Pinus koraiensis, Larix leptolepis and Quercus acutissima stands at the Gongju city of Chungnam Province, Korea. Annual mean air temperature is $11.9^{\circ} \mathrm{C}$ and total annual precipitation averages $1,534 \mathrm{~mm}$. The elevation range of the study site was $94 \sim 214 \mathrm{~m}$. The average age of the Pinus densiflora stand was 36 years and the number of trees per ha are 1,331. The average age of the Pinus koraiensis stand was 39 years and the number of trees per ha was 1,206 . The average age of the Larix leptolepis stand was 36 years and the number of trees per ha was 588. The average age of the Quercus acutissima stand was 42 years and the number of trees per ha was 363. The study sites was dominated by Smilax china, Oplismenus undulatifolius, Corylus heterophylla, Rhus trichocarpa, Lindera obtusiloba and platycarya strobilacea. The soil is brown forest soil, a representative soil of Korea.

For this study, three $10 \mathrm{~m} \times 10 \mathrm{~m}$ permanent plots, which was established on a relatively similar slope, aspect and soil, were randomly selected in each stand. Fine root biomass was established by monthly soil coring from April to November at five random locations in each plot (Hwang 1996; Makkonen and Helmisaari, 1999). Sample points for coring were randomly selected from the permanent grid. A stainless steel core $(7.4 \mathrm{~cm}$ diameter and 
Table 1. Equations used for estimating fine root production (Fairely and Alexander, 1985)

\begin{tabular}{ccc}
\hline${ }^{\triangle}$ Live root biomass & ${ }^{\triangle}$ Dead root biomass & Production equations \\
\hline Increase & Increase & $\mathrm{P}={ }^{\triangle} \mathrm{B}_{\text {live }}+{ }^{\triangle} \mathrm{B}_{\text {dead }}$ \\
Decrease & Increase & $\mathrm{P}=0$ or ${ }^{\circ} \mathrm{B}_{\text {live }}+{ }^{\triangle} \mathrm{B}_{\text {Dead }}$ \\
Increase & Decrease & $\mathrm{P}={ }^{\triangle} \mathrm{B}_{\text {live }}$ \\
Decrease & Decrease & $\mathrm{P}=0$ \\
\hline
\end{tabular}

All analysis was conducted using the general linear model procedure of the statistical analysis system(SAS, 1988). Tukey's HSD test was used to statistically separate mean test of significance were at the 0.05 level unless otherwise stated.

$30 \mathrm{~cm}$ long) was used to take soil sample.

Samples were returned to the laboratory and stored at $4{ }^{\circ} \mathrm{C}$ until they were processed (Hwang, 1996; Burke and Raynal, 1994). Roots from mineral soil were wet sieved using a $2 \mathrm{~mm}$ mesh screen and fragmented root that passed the screen were hand sorted(Hwang, 1996; Burke and Raynal, 1994). Fine roots (<2 mm) were sorted and classified as live and dead on the basis of morphology, flotation and color with careful microscopic observation. Roots were then dried to a constant mass at $65^{\circ} \mathrm{C}$ and weighed. Dried fine root samples were ground for carbon concentration.

In this study, fine root production was calculated by balancing the monthly live and dead fine root biomass according to the decision matrix presented by Fairly and Alexander (1985) (Table 1). Fine root turnover was calculated as the ratio of fine root production to biomass (Burke and Raynal, 1994). Fine root subsamples were used for organic matter analysis by loss on ignition.

\section{RESULTS AND DISCUSSION}

The average fine root carbon biomass (live + dead) in Pinus densiflora, Pinus koraiensis, Larix leptolepis and Quercus acutissima stands was higher at the 0 30 cm soil depth than in the other soil depths (Tables 2, 3, 4 and 5). The average fine root carbon biomass ( $\mathrm{kg}$ $\mathrm{ha}^{-1}$ ) in Pinus densiflora, Pinus koraiensis, Larix leptolepis and Quercus acutissima stands were $889 \mathrm{~kg}$, $2,266 \mathrm{~kg}, 851 \mathrm{~kg}$, and 1,121 kg at 0-30 cm soil depth, respectively. The fine root carbon biomass was similar with in Pinus rigida plantation of Korea $\left(1,322 \mathrm{~kg} \mathrm{ha}^{-1}\right.$; Hwang, 1996) and hardwood stands of Northeast U.S.A $\left(1,150 \mathrm{~kg} \mathrm{ha}^{-1}\right.$; Burke and Raynal, 1984). The total fine root carbon biomass was ranged from $1,703.1 \mathrm{~kg}$ to $2,151.7 \mathrm{~kg}$ at $0-90 \mathrm{~cm}$ soil depth in the four study stands. As shown in Tables 2, 3, 4 and 5, the total fine root carbon biomass was highest in Larix leptolepis among the study stands.

Seasonal changes in fine root carbon biomass of the Pinus densiflora, Pinus koraiensis, Larix leptolepis and Quercus acutissima stands varied among sampling times. Major peak in fine root carbon biomass was found in April and July in the Pinus densiflora stand (Table 2), April in Pinus koraiensis stand (Table 3), June in Larix leptolepis Stand (Table 4) and also May and August in Quercus acutissima stands (Table 5). However, Burke and Raynal (1994) reported the fine

Table 2. Fine root carbon biomass $\left(\mathrm{kg} \mathrm{ha}^{-1}\right)$ in Pinus densiflora stand at $0-30 \mathrm{~cm}, 30-60 \mathrm{~cm}$, and 60-90 cm soil depths. The number in parenthesis is one standard error of the mean ( $\mathrm{n}=12$ at $0-30 \mathrm{~cm}$ and $30-60 \mathrm{~cm}, \mathrm{n}=6$ at $60-90 \mathrm{~cm})$

\begin{tabular}{|c|c|c|c|c|c|c|c|c|c|}
\hline Soil depth & 22 Apr. & 20 May. & 20 Jun. & 22 Jul. & 22 Aug. & 21 Sep. & 20 Oct. & 23 Nov. & Mean \\
\hline $0-30 \mathrm{~cm}$ & $\begin{array}{c}1556.3 \\
(353)\end{array}$ & $\begin{array}{c}1056.1 \\
(103)\end{array}$ & $\begin{array}{c}1267.8 \\
(176)\end{array}$ & $\begin{array}{c}1495.8 \\
(385)\end{array}$ & $\begin{array}{l}977.0 \\
(131)\end{array}$ & $\begin{array}{l}786.3 \\
(148)\end{array}$ & $\begin{array}{c}623.5 \\
(91)\end{array}$ & $\begin{array}{l}763.0 \\
(175)\end{array}$ & 1065.7 \\
\hline $30-60 \mathrm{~cm}$ & $\begin{array}{c}482.7 \\
(55)\end{array}$ & $\begin{array}{c}279.2 \\
(62)\end{array}$ & $\begin{array}{c}369.9 \\
(83)\end{array}$ & $\begin{array}{l}474.6 \\
(143)\end{array}$ & $\begin{array}{c}393.1 \\
(72)\end{array}$ & $\begin{array}{c}314.1 \\
(45)\end{array}$ & $\begin{array}{c}230.3 \\
(36)\end{array}$ & $\begin{array}{l}551.3 \\
(137)\end{array}$ & 386.9 \\
\hline $60-90 \mathrm{~cm}$ & $\begin{array}{c}412.5 \\
(60)\end{array}$ & $\begin{array}{c}318.7 \\
(57)\end{array}$ & $\begin{array}{c}228.0 \\
(56)\end{array}$ & $\begin{array}{l}323.4 \\
(125)\end{array}$ & $\begin{array}{c}230.3 \\
(35)\end{array}$ & $\begin{array}{c}183.8 \\
(49)\end{array}$ & $\begin{array}{c}141.9 \\
(38)\end{array}$ & $\begin{array}{c}165.2 \\
(42)\end{array}$ & 250.5 \\
\hline $0-90 \mathrm{~cm}$ & & & & & & & & & 1703.1 \\
\hline
\end{tabular}

Table 3. Fine root carbon biomass $\left(\mathrm{kg} \mathrm{ha}^{-1}\right)$ in Pinus koraiensis stand at $0-30 \mathrm{~cm}, 30-60 \mathrm{~cm}$, and $60-90 \mathrm{~cm}$ soil depths. The number in parenthesis is one standard error of the mean ( $\mathrm{n}=12$ at $0-30 \mathrm{~cm}$ and $30-60 \mathrm{~cm}, \mathrm{n}=6$ at $60-90 \mathrm{~cm}$ )

\begin{tabular}{|c|c|c|c|c|c|c|c|c|c|}
\hline Soil depth & 22 Apr. & 20 May. & 20 Jun. & 22 Jul. & 22 Aug. & 21 Sep. & 20 Oct. & 23 Nov. & Mean \\
\hline $0-30 \mathrm{~cm}$ & $\begin{array}{c}2097.0 \\
(349)\end{array}$ & $\begin{array}{c}1447.0 \\
(439)\end{array}$ & $\begin{array}{c}1756.4 \\
(293)\end{array}$ & $\begin{array}{l}853.8 \\
(143)\end{array}$ & $\begin{array}{c}1751.7 \\
(143)\end{array}$ & $\begin{array}{l}774.7 \\
(140)\end{array}$ & $\begin{array}{l}904.9 \\
(151)\end{array}$ & $\begin{array}{c}1214.3 \\
(226)\end{array}$ & 1350.0 \\
\hline $30-60 \mathrm{~cm}$ & $\begin{array}{l}405.0 \\
(113)\end{array}$ & $\begin{array}{c}188.4 \\
(50)\end{array}$ & $\begin{array}{c}318.7 \\
(81)\end{array}$ & $\begin{array}{c}269.9 \\
(68)\end{array}$ & $\begin{array}{c}337.3 \\
(61)\end{array}$ & $\begin{array}{c}321.0 \\
(56)\end{array}$ & $\begin{array}{c}258.2 \\
(66)\end{array}$ & $\begin{array}{c}309.4 \\
(72)\end{array}$ & 301.0 \\
\hline $60-90 \mathrm{~cm}$ & $\begin{array}{l}74.0 \\
(32)\end{array}$ & $\begin{array}{c}134.9 \\
(29)\end{array}$ & $\begin{array}{c}148.9 \\
(71)\end{array}$ & $\begin{array}{c}162.8 \\
(45)\end{array}$ & $\begin{array}{c}300.1 \\
(92)\end{array}$ & $\begin{array}{c}225.7 \\
(76)\end{array}$ & $\begin{array}{c}193.1 \\
(46)\end{array}$ & $\begin{array}{c}144.2 \\
(57)\end{array}$ & 173.9 \\
\hline $0-90 \mathrm{~cm}$ & & & & & & & & & 1844.8 \\
\hline
\end{tabular}


Table 4. Fine root carbon biomass $\left(\mathrm{kg} \mathrm{ha}^{-1}\right)$ in Larix leptolepis stand at $0-30 \mathrm{~cm}, 30-60 \mathrm{~cm}$, and $60-90 \mathrm{~cm}$ soil depths. The number in parenthesis is one standard error of the mean ( $\mathrm{n}=12$ at $0-30 \mathrm{~cm}$ and $30-60 \mathrm{~cm}, \mathrm{n}=6$ at $60-90 \mathrm{~cm})$

\begin{tabular}{|c|c|c|c|c|c|c|c|c|c|}
\hline Soil depth & 22 Apr. & 20 May. & 20 Jun. & 22 Jul. & 22 Aug. & 21 Sep. & 20 Oct. & 23 Nov. & Mean \\
\hline $0-30 \mathrm{~cm}$ & $\begin{array}{c}1326.0 \\
(195)\end{array}$ & $\begin{array}{c}1340.0 \\
(181)\end{array}$ & $\begin{array}{c}1833.1 \\
(146)\end{array}$ & $\begin{array}{c}1542.3 \\
263)\end{array}$ & $\begin{array}{c}1770.3 \\
(202)\end{array}$ & $\begin{array}{c}1765.7 \\
(343)\end{array}$ & $\begin{array}{c}1279.5 \\
(222)\end{array}$ & $\begin{array}{l}663.0 \\
(110)\end{array}$ & 1440.0 \\
\hline $30-60 \mathrm{~cm}$ & $\begin{array}{l}519.7 \\
(107)\end{array}$ & $\begin{array}{c}274.5 \\
(54)\end{array}$ & $\begin{array}{l}497.8 \\
(122)\end{array}$ & $\begin{array}{l}483.9 \\
(173)\end{array}$ & $\begin{array}{l}593.2 \\
(123)\end{array}$ & $\begin{array}{c}339.6 \\
(71)\end{array}$ & $\begin{array}{c}481.5 \\
(82)\end{array}$ & $\begin{array}{l}428.0 \\
(114)\end{array}$ & 452.3 \\
\hline $60-90 \mathrm{~cm}$ & $\begin{array}{c}160.9 \\
(67)\end{array}$ & $\begin{array}{l}437.3 \\
(120)\end{array}$ & $\begin{array}{c}214.0 \\
(68)\end{array}$ & $\begin{array}{c}239.6 \\
(81)\end{array}$ & $\begin{array}{l}244.3 \\
(110)\end{array}$ & $\begin{array}{c}181.5 \\
(47)\end{array}$ & $\begin{array}{c}323.4 \\
(57)\end{array}$ & $\begin{array}{c}274.5 \\
(71)\end{array}$ & 259.4 \\
\hline $0-90 \mathrm{~cm}$ & & & & & & & & & 2151.7 \\
\hline
\end{tabular}

Table 5. Fine root carbon biomass $\left(\mathrm{kg} \mathrm{ha}^{-1}\right)$ in Quercus acutissima stand at 0-30 cm, 30-60 cm, and 60-90 cm soil depths. The number in parenthesis is one standard error of the mean ( $\mathrm{n}=12$ at $0-30 \mathrm{~cm}$ and $30-60 \mathrm{~cm}, \mathrm{n}=6$ at $60-90 \mathrm{~cm})$

\begin{tabular}{|c|c|c|c|c|c|c|c|c|c|}
\hline Soil depth & 22 Apr. & 20 May. & 20 Jun. & 22 Jul. & 22 Aug. & 21 Sep. & 20 Oct. & 23 Nov. & Mean \\
\hline $0-30 \mathrm{~cm}$ & $\begin{array}{c}1493.5 \\
(172)\end{array}$ & $\begin{array}{c}1677.3 \\
(244)\end{array}$ & $\begin{array}{c}1565.6 \\
(127)\end{array}$ & $\begin{array}{c}1107.3 \\
(144)\end{array}$ & $\begin{array}{c}1777.3 \\
(316)\end{array}$ & $\begin{array}{c}1267.8 \\
(187)\end{array}$ & $\begin{array}{l}895.6 \\
(120)\end{array}$ & $\begin{array}{l}665.3 \\
(138)\end{array}$ & 1306.2 \\
\hline $30-60 \mathrm{~cm}$ & $\begin{array}{c}469.9 \\
(85)\end{array}$ & $\begin{array}{c}467.6 \\
(95)\end{array}$ & $\begin{array}{c}465.3 \\
(72)\end{array}$ & $\begin{array}{c}362.9 \\
(84)\end{array}$ & $\begin{array}{l}586.2 \\
(165)\end{array}$ & $\begin{array}{c}325.7 \\
(57)\end{array}$ & $\begin{array}{l}456.0 \\
(151)\end{array}$ & $\begin{array}{c}402.5 \\
(67)\end{array}$ & 442.0 \\
\hline $60-90 \mathrm{~cm}$ & $\begin{array}{c}323.4 \\
(93)\end{array}$ & $\begin{array}{l}430.4 \\
(117)\end{array}$ & $\begin{array}{c}307.1 \\
(85)\end{array}$ & $\begin{array}{c}172.1 \\
(56)\end{array}$ & $\begin{array}{l}367.6 \\
(134)\end{array}$ & $\begin{array}{l}162.8 \\
(409)\end{array}$ & $\begin{array}{c}172.1 \\
(52)\end{array}$ & $\begin{array}{l}69.8 \\
(56)\end{array}$ & 250.7 \\
\hline $0-90 \mathrm{~cm}$ & & & & & & & & & 1998.9 \\
\hline
\end{tabular}

root biomass in Northeast hardwood stands of U.S.A. was peak in May. Also, McClaugherty et al. (1982) reported highest fine root biomass in spring season.

Net fine root carbon production $\left(\mathrm{kg} \mathrm{ha}^{-1} \mathrm{yr}^{-1}\right)$ in Pinus densiflora, Pinus koraiensis, Larix leptolepis and Quercus acutissima stands were $889 \mathrm{~kg}, 2,266 \mathrm{~kg}$, $851 \mathrm{~kg}$, and $1,121 \mathrm{~kg}$ at $0-30 \mathrm{~cm}$ soil depth, respectively (Table 6, 7, 8, and 9). The net fine root carbon production was more than in Pinus rigida plantation forests of Korea (671 kg at 0-20 cm; Hwang, 1997) and more or lower than in Northeast hardwood stands of U.S.A. $\left(1,100 \mathrm{~kg} \mathrm{ha}^{-1}\right.$; Burke and Raynal, 1994). The net fine root carbon production in the four study stands was also higher at $0-30 \mathrm{~cm}$ soil depth than in other soil depths.
As shown in Tables 6, 7, 8 and 9, the net fine root carbon production $0-30 \mathrm{~cm}$ soil depth was highest in Pinus koraiensis stand among the study stand.

Total fine root NPP at $0-90 \mathrm{~cm}$ were $1,731 \mathrm{~kg}$, $3,092 \mathrm{~kg}, 2,249 \mathrm{~kg}$ and 2,068 kg in Pinus densiflora, Pinus koraiensis, Larix leptolepis and Quercus acutissima stands, respectively (Tables 6, 7, 8 and 9). These were very similar to those for Northeast hardwood stands of U.S.A. (2,000-2,500 kg at 0-100 cm soil depths; Raynal and Burke, 1994). Park (2001) reported that net primary carbon production by leaves was $1,100 \mathrm{~kg}, 1,200 \mathrm{~kg}$, and $1,200 \mathrm{~kg}$ in Quercus mongolica stands in Gongju, Pohang, and Yanyang area of Korea. This result indicates the important role of fine root to carbon cycle in for-

Table 6. Net fine root carbon production $\left(\mathrm{kg} \mathrm{ha}^{-1} \mathrm{yr}^{-1}\right)$ in Pinus densiflora stand of Gongju area at 0-30 cm, $30-60 \mathrm{~cm}$, and $60-90 \mathrm{~cm}$ soil depths

\begin{tabular}{ccccccccc}
\hline $\begin{array}{c}\text { Soil depth } \\
(\mathrm{cm})\end{array}$ & $\begin{array}{c}\text { 22 Apr. } \\
\sim 20 \text { May. }\end{array}$ & $\begin{array}{c}\text { 20 May. } \\
\sim 20 \mathrm{Jun} .\end{array}$ & $\begin{array}{c}\text { 20 Jun. } \\
\sim 22 \mathrm{Jul} .\end{array}$ & $\begin{array}{c}\text { 22 Jul. } \\
\sim 22 \text { Aug }\end{array}$ & $\begin{array}{c}\text { 22 Aug. } \\
\sim 21 \text { Sep. }\end{array}$ & $\begin{array}{c}\text { 21 Sep. } \\
\sim 20 \text { Oct. }\end{array}$ & $\begin{array}{c}\text { 20 Oct. } \\
\sim 23 \text { Nov. }\end{array}$ & Total \\
\hline $0-30$ & 0 & 212 & 330 & 0 & 0 & 0 & 347 & 889 \\
$30-60$ & 0 & 91 & 105 & 0 & 0 & 0 & 435 & 630 \\
$60-90$ & 0 & 0 & 95 & 0 & 0 & 0 & 116 & 212 \\
\hline $0-90$ & & & & & & & 1731 \\
\hline
\end{tabular}

Table 7. Net fine root carbon production $\left(\mathrm{kg} \mathrm{ha}^{-1} \mathrm{yr}^{-1}\right)$ in Pinus koraiensis stand of Gongju area at 0-30 cm, 30-60 cm, and $60-90 \mathrm{~cm}$ soil depths

\begin{tabular}{ccccccccc}
\hline $\begin{array}{c}\text { Soil depth } \\
(\mathrm{cm})\end{array}$ & $\begin{array}{c}\text { 22 Apr. } \\
\sim 20 \text { May. }\end{array}$ & $\begin{array}{c}\text { 20 May. } \\
\sim 20 \text { Jun. }\end{array}$ & $\begin{array}{c}\text { 20 Jun. } \\
\sim 22 \text { Jul. }\end{array}$ & $\begin{array}{c}\text { 22 Jul. } \\
\sim 22 \text { Aug }\end{array}$ & $\begin{array}{c}\text { 22 Aug. } \\
\sim 21 \text { Sep. }\end{array}$ & $\begin{array}{c}\text { 21 Sep. } \\
\sim 20 \text { Oct. }\end{array}$ & $\begin{array}{c}20 \text { Oct. } \\
\sim 23 \text { Nov. }\end{array}$ & $\begin{array}{c}\text { Total } \\
\text { 20 }\end{array}$ \\
\hline $0-30$ & 0 & 309 & 0 & 1333 & 0 & 130 & 493 \\
$30-60$ & 0 & 130 & 0 & 167 & 0 & 0 & 142 \\
$60-90$ & 140 & 14 & 14 & 219 & 0 & 0 & 340 \\
\hline $0-90$ & & & & & & 3096 \\
\hline
\end{tabular}


Table 8. Net fine root carbon production $\left(\mathrm{kg} \mathrm{ha}^{-1} \mathrm{yr}^{-1}\right)$ in Larix leptolepis stand of Gongju area at 0-30 cm, $30-60 \mathrm{~cm}$, and $60-90 \mathrm{~cm}$ soil depths

\begin{tabular}{ccccccccc}
\hline $\begin{array}{c}\text { Soil depth } \\
(\mathrm{cm})\end{array}$ & $\begin{array}{c}\text { 22 Apr. } \\
\sim 20 \text { May. }\end{array}$ & $\begin{array}{c}\text { 20 May. } \\
\sim 20 \mathrm{Jun} .\end{array}$ & $\begin{array}{c}\text { 20 Jun. } \\
\sim 22 \mathrm{Jul} .\end{array}$ & $\begin{array}{c}\text { 22 Jul. } \\
\sim 22 \text { Aug }\end{array}$ & $\begin{array}{c}\text { 22 Aug. } \\
\sim 21 \text { Sep. }\end{array}$ & $\begin{array}{c}\text { 21 Sep. } \\
\sim 20 \text { Oct. }\end{array}$ & $\begin{array}{c}\text { 20 Oct. } \\
\sim 23 \text { Nov. }\end{array}$ & Total \\
\hline $0-30$ & 14 & 439 & 0 & 344 & 0 & 0 & 0 & 851 \\
$30-60$ & 0 & 244 & 0 & 330 & 0 & 142 & 0 & 717 \\
$60-90$ & 293 & 0 & 26 & 65 & 0 & 298 & 0 & 681 \\
\hline $0-90$ & & & & & & & 2249 \\
\hline
\end{tabular}

Table 9. Net fine root carbon production $\left(\mathrm{kg} \mathrm{ha}^{-1} \mathrm{yr}^{-1}\right)$ in Quercus acutissima stand of Gongju area at 0-30 cm, $30-60 \mathrm{~cm}$, and 60-90 cm soil depths

\begin{tabular}{cccccccrr}
\hline $\begin{array}{c}\text { Soil depth } \\
(\mathrm{cm})\end{array}$ & $\begin{array}{c}\text { 22 Apr. } \\
\sim 20 \text { May. }\end{array}$ & $\begin{array}{c}\text { 20 May. } \\
\sim 20 \mathrm{Jun} .\end{array}$ & $\begin{array}{c}\text { 20 Jun. } \\
\sim 22 \mathrm{Jul} .\end{array}$ & $\begin{array}{c}\text { 22 Jul. } \\
\sim 22 \text { Aug }\end{array}$ & $\begin{array}{c}\text { 22 Aug. } \\
\sim 21 \text { Sep. }\end{array}$ & $\begin{array}{c}\text { 21 Sep. } \\
\sim 20 \text { Oct. }\end{array}$ & $\begin{array}{c}\text { 20 Oct. } \\
\sim 23 \text { Nov. }\end{array}$ & Total \\
\hline $0-30$ & 249 & 0 & 0 & 872 & 0 & 0 & 0 & 1121 \\
$30-60$ & 0 & 0 & 0 & 344 & 0 & 130 & 0 & 475 \\
$60-90$ & 153 & 0 & 0 & 319 & 0 & 0 & 0 & 472 \\
\hline $0-90$ & & & & & & & 2068 \\
\hline
\end{tabular}

Table 10. Fine root turnover rate (\%/yr) in Pinus densiflora, Larix leptolepis, Pinus koraiensis, and Quercus acutissima Stand in Gongju area at $0-30 \mathrm{~cm}, 30-60 \mathrm{~cm}$, and $60-90 \mathrm{~cm}$ soil depths.

\begin{tabular}{ccccc}
\hline Soil depth $(\mathrm{cm})$ & Pinus densiflora & Pinus koraiensis & Larix leptolepis & Quercus acutissima \\
\hline $0-30$ & 0.83 & 1.68 & 0.59 & 0.86 \\
$30-60$ & 1.63 & 1.46 & 1.58 & 1.07 \\
$60-90$ & 0.85 & 2.24 & 2.63 & 1.88 \\
\hline
\end{tabular}

est ecosystems like other reports (Hansen, 1993; Cooper, 1983; Burke and Raynal, 1994). As shown in Tables 6, 7 , 8 and 9 , the total net fine root carbon production in 0-90 cm soil depth was highest in Pinus koraiensis stand among the study stand.

Fine root turnover rate (yr) was ranged from 0.59 to 2.63 (Table 10). This rate was in the range of the rate reported by Vogt and Bloomfield (1991). In this study, the fine root turnover rates were lower at $0-30 \mathrm{~cm}$ soil depth than the other soil depths except Pinus koraiensis stand. It was reported that low rates of fine root turnover was on relatively poor site (Mooney and Gulman, 1982). However, fine root turnover may vary with site quality and species composition (Shaver and Billings, 1975).

\section{REFERENCES}

Burke, M. K. and D. J. Raynal 1994 Fine root growth phenology, production, and turnover in a northern hardwood forest ecosystem. Plant and Soil 162: 135-146

Cooper, C. F. 1983 Carbon storage in managed forests. Can. J. For. Res. 13: 155-166

Fairly, R. I. and I. J. Alexander 1985 Methods of calculating fine root production in forests. In: Ecological interactions in the soil. special publication no. 4 of the British Ecol. Soc. pp. 37-41. London

Hair, D. and R. N. Sampson 1992 Climate change-history. Prospects, and possible impacts. pp. 1-10 In: Sampson, R. N. and Hair, D. (eds.) Forests and Global Change. Vol. I: Opportunities for Increasing Forest Cover. Am. For.
Washington, D. C.

Hansen, E. A. 1992 Soil carbon sequestration beneath hybrid poplar plantations. Nor. Cen. For. Exp. Sta. USDA For. Serv. For. Sci. Lab. Grand Rapids, MN, 55744: p. 13

Hwang, J.-H. 1996 Effects of fertilization on fine root dynamics in pitch pine and Japanese Larch Plantations. Master Thesis, Korea University

Laurenroth, W. K., H. W. Hunt, D. M. Swift and J. S. Singh 1998 Reply to Vogt et al. Ecology 67: 580-582

Makkonen, K. and H. S. Helmisaari 1999 Assessing fine root biomass and production in a Scots pine stand-comparison of soil core and root in growth core methods. Plant and Soil 210: $43-50$

McClaugherty, C. A., J. D. Aberand and J. M. Melillo 1982 Decomposition dynamics of fine roots in forested ecosystems. Oikos 42: 378-386

Nadelhoffer, K. J. and J. W. Raich 1992 Fine root production estimates and belowground carbon allocation in forest ecosystems. Ecology 73: 1139-1147

Park, G. S. and S. W. Lee 2001 Biomass and net primary production of Quercus variabilis natural forest ecosystems in Gongju, Pohang, and Yangtang of korea. J. Korean For. Soc. 90: $692-698$

Schlesinger, W. H. 1991 Biogeochemistry; an Analysis of Global change. Academic press, N. Y. p. 443

Shaver, G. R. and W. D. Billings 1975 Root production and root turnover in a wet Tundra ecosystem, Barrow, Alaska. Ecology 56: $401-409$

Singh, J. S., W. K. Laurenroth, H. W. Hunt and D. M. Swift 1984 Bias and random errors in estimators of net root production: a simulation approach. Ecology 65: 1760-1764

Vogt, K. A., C. C. Grier, S. T. Bower, D. G. Sprugel, and D. J. Vogt 1986 Overestimation of net root production: a real or imaginary problem? Ecology 67: 577-579 